\title{
WHAT EXPLAINS THE COVID-19 STOCK MARKET?
}

\author{
Josue Cox \\ Daniel L. Greenwald \\ Sydney C. Ludvigson \\ Working Paper 27784 \\ http://www.nber.org/papers/w27784
NATIONAL BUREAU OF ECONOMIC RESEARCH
1050 Massachusetts Avenue
Cambridge, MA 02138
September 2020

Ludvigson is grateful to the CV Starr Center for Applied Economics, at NYU for financial support. We are grateful to Aleksandra Alferova for excellent research assistance. The views expressed herein are those of the authors and do not necessarily reflect the views of the National Bureau of Economic Research.

NBER working papers are circulated for discussion and comment purposes. They have not been peer-reviewed or been subject to the review by the NBER Board of Directors that accompanies official NBER publications.

(C) 2020 by Josue Cox, Daniel L. Greenwald, and Sydney C. Ludvigson. All rights reserved. Short sections of text, not to exceed two paragraphs, may be quoted without explicit permission provided that full credit, including $(\subset$ notice, is given to the source. 
What Explains the COVID-19 Stock Market?

Josue Cox, Daniel L. Greenwald, and Sydney C. Ludvigson

NBER Working Paper No. 27784

September 2020

JEL No. G12,G28

\begin{abstract}
What explains stock market behavior in the early weeks of the coronavirus pandemic? Estimates from a dynamic asset pricing model point to wild fluctuations in the pricing of stock market risk, driven by shifts in risk aversion or sentiment. We find further evidence that the Federal Reserve played a role in these fluctuations, via a series of announcements outlining unprecedented steps to provide several trillion dollars in loans to support the economy. As of July 31 of 2020, however, only a tiny fraction of the credit that the central bank announced it stood ready to provide in early April had been extended, reinforcing the conclusion that market movements during COVID-19 have been more reflective of sentiment than substance.
\end{abstract}

Josue Cox

Department of Economics

New York University

josue.cox@nyu.edu

Daniel L. Greenwald

MIT Sloan School of Management

100 Main Street, E62-641

Cambridge, MA 02142

dlg@mit.edu
Sydney C. Ludvigson

Department of Economics

New York University

19 W. 4th Street, 6th Floor

New York, NY 10002

and NBER

sydney.ludvigson@nyu.edu 


\section{Introduction}

By February of 2020, the coronavirus 2019 (COVID-19) pandemic had set in motion a worldwide disruption in economic activity, causing the U.S. unemployment rate to reach $14.7 \%$ in April. The S\&P 500 stock market index initially reacted to news of the disease by losing $33.7 \%$ of its value between February 19 and March 23 of 2020. But the market abruptly regained the vast majority of this lost value, rising 29\% between March 24 and April 17, a surge that left the index back where it stood in August of 2019 when the U.S. economy was booming and the unemployment rate was $3.7 \%$.

What explains this sharp V-shaped trajectory of the U.S. stock market that took place over a matter of weeks in the early stages of COVID-19? The objective of this study is to address this question. The investigation consists of two parts. The first part employs the theoretical model of Greenwald, Lettau, and Ludvigson (2019) (GLL), along with updated estimates of that model, to decompose the market's changes into distinct component sources attributable to fluctuations in aggregate economic fundamentals, interest rates, corporate earnings shares, and/or discount rate fluctuations driven by the pricing of stock market risk. Estimates of this model imply that it is difficult if not impossible to explain the market's V-shaped trajectory during the COVID-19 crisis with plausible fluctuations in aggregate economic activity, corporate profit shares, or short-term interest rates. Instead, the estimates point toward wild volatility in the pricing of stock market risk, driven by fluctuations in risk aversion or beliefs/sentiment. ${ }^{1}$

The second part of this study investigates what role, if any, Federal Reserve actions might have played in these fluctuations. ${ }^{2}$ Specifically, we use a high-frequency event study to explore the role of central bank communications during March and April of 2020. We find no evidence that "conventional" monetary policy announcements promulgating decisions to lower the target range for the federal funds rate to near zero or to increase the Federal

\footnotetext{
${ }^{1}$ Gormsen and Koijen (2020) reach a similar conclusion by studying S\&P dividend futures to compute a lower bound on growth expectations.

${ }^{2} \mathrm{~A}$ widely shared belief among investment professionals is that the stock market is highly sensitive to the actions of the Federal Reserve. See Baker, Bloom, Davis, and Sammon (2019) who conduct systematic analysis of newspaper articles on the days after major stock market jumps.
} 
Reserve's holdings of Treasury securities and agency MBS were a contributing factor in the market rebound. Conversely, we do find evidence that several "unconventional" monetary policy announcements outlining the central bank's unprecedented steps to provide several trillion dollars in loans to support the economy played a role in the market turnabout. Specifically, the 30-minute windows bracketing five of these announcements are collectively associated with gains of approximately $8 \%$ in the S\&P 500 stock market index and $12 \%$ in the Russell 2000 index.

However, as of July 31 of 2020, only a tiny fraction of the credit that the central bank announced it stood ready to provide in early April had been extended. And as of August 19 of 2020, the market had yet to give up any of the gains it made starting in late March; indeed several indexes had reached record highs. Taken together, this evidence suggests that Federal Reserve communications during the early weeks of the coronavirus pandemic influenced markets mainly by altering risk tolerance, reinforcing the model-based conclusion that market movements during COVID-19 have been more reflective of sentiment than substance.

The rest of this paper is organized as follows. The next section describes the GLL asset pricing model, its estimation, and model results pertaining to the COVID-19 economic shock. Section 3 discusses the event study of Federal Reserve announcements during March and April of 2020. Section 4 concludes.

\section{Modeling Market Movements}

This section provides an adumbrated description of the GLL model and its estimation, along with how its modified to study the COVID-19 shock to the economy. We refer the reader to GLL for the full model details.

The GLL model is designed to address the question: What are the economic foundations of stock market fluctuations? The framework is set up so that it can answer the question regarding fluctuations over any desired horizon. It is therefore straightfoward to focus on specific episodes. To translate raw data into a quantitative decomposition of the sources of growth in stocks, GLL construct and estimate a flexible parametric model of the U.S. equity market that allows for influence from a number of mutually uncorrelated latent factors, 
including not only factors driving overall economic output and corporate profit shares, but also independent factors driving risk premia and risk-free interest rates.

Equity in GLL is priced, not by a representative household, but by a representative shareholder, akin in the data to a wealthy household or large institutional investor. Shareholder preferences are subject to shocks that alter their patience and appetite for risk, driving variation in both risk-free interest rates and the equity risk premium. Shareholders understand the laws of motion for these shocks and internalize them when forming expectations. The representative shareholder consumes cash flows from firms, the variation of which is driven by shocks to the total rewards generated by productive activity, but also by shocks to how those rewards are divided between shareholders and other claimants.

The intertemporal marginal rate of substitution of shareholder consumption, $C_{t}$, is the stochastic discount factor (SDF) and takes the form

$$
\ln M_{t+1}=-\mathbf{1}^{\prime} \delta_{t}-d_{t}-x_{t} \Delta \ln C_{t+1}
$$

where the subjective time discount factor $\beta_{t} \equiv \exp \left(-\left[\delta_{t}+d_{t}\right]\right)$. The stochastic process $\delta_{t}=\mathbf{1}^{\prime} \boldsymbol{\delta}_{t}$, where $\boldsymbol{\delta}_{t}$ is a bivariate vector containing low- and high-frequency components, is a latent shock to the subjective time-discount factor that moves the risk-free rate independently of the aggregate economic state. The parameter $d_{t}$ is a compensating factor chosen to ensure that the $\log$ risk-free rate $r_{f, t}=-\ln \mathbb{E}_{t} \exp \left(m_{t+1}\right)$ obeys an empirically accurate process that exactly matches an observed proxy for the risk-free rate of interest. The parameter $x_{t}$ is a latent state variable that governs the pricing of stock market risk. Since an SDF always reflects both preferences and beliefs, an increase in $x_{t}$ may be thought of as either an increase in effective risk aversion or an increase in pessimism about shareholder payout. The GLL model allows this variable to contain a component that is correlated with the earnings share of output, and a component that is uncorrelated with all other economic state variables. The mutually uncorrelated latent risk price shock is denoted $x_{\perp, t} \equiv \mathbf{1}^{\prime} \mathbf{x}_{\perp, t}$, and is modeled as the sum of estimated low- and high-frequency components contained in the $2 \times 1$ vector $\mathbf{x}_{\perp, t}$.

In equilibrium, shareholder consumption $C_{t+1}$ is equal to equity payout, which we refer to simply as "cash flow." Let lowercase letters denote log variables, e.g., $\ln \left(C_{t}\right)=c_{t}$. Denote 
the log stock price $p_{t}$. The log difference of cash flows in the model obeys

$$
\Delta c_{t}=\boldsymbol{\xi}^{\prime} \Delta \mathbf{s}_{t}+\Delta y_{t},
$$

where $y_{t}$ is $\log$ of aggregate economic output. The vector $\mathbf{s}_{t}$ contains low- and high-frequency components of the after-tax corporate earnings share, while $\boldsymbol{\xi}^{\prime} \equiv(\xi, \xi)^{\prime}$ is a constant vector that contains an "operating leverage" parameter $\xi>1$ that arises from the need for firms in aggregate to retain part of their earnings for reinvestment before making any payout.

Although the estimates of output growth in GLL suggest that their autocorrelations hover around zero, thereby suggesting a near i.i.d. process for $\Delta y_{t}$, the Covid-19 economic crisis might reasonably be interpreted as having a large transitory component to it. To accommodate a transitory drop in output, we augment the GLL model with a transitory component, denoted $z_{t}$, that follows

$$
z_{t+1}=\phi_{z} z_{t}+\varepsilon_{z, t+1}, \quad \varepsilon_{z, t+1} \sim N\left(0, \sigma_{z}^{2}\right)
$$

which implies

$$
\Delta z_{t+1}=-\left(1-\phi_{z}\right) z_{t}+\varepsilon_{z, t+1}
$$

Total output growth is defined by

$$
\begin{aligned}
\Delta y_{t+1} & =g+\Delta z_{t+1}+\varepsilon_{a, t+1} \\
& =g-\left(1-\phi_{z}\right) z_{t}+\varepsilon_{z, t+1}+\varepsilon_{a, t+1} .
\end{aligned}
$$

The transitory $\varepsilon_{z, t+1}$ shock is designed to capture any temporary output drop attributable to the Covid-19 event, which, although sharp, may be short-lived due to the temporary nature of lockdowns and the possibility of a vaccine arriving in the relatively near future. To incorporate the unexpected nature of this shock without adjusting our previous estimates, we assume that agents perceive $\sigma_{z}=0$, and are completely surprised by a nonzero realization of this shock in 2020:Q1. For simplicity, we assume that agents maintain their belief $\sigma_{z}=0$ going forward, and interpret the drop in output following the arrival of Covid-19 as a one-time event.

Solving the model under these assumptions yields the solution for the log price-payout ratio $p_{t}-c_{t}$, denoted $p c_{t}$ :

$$
p c_{t}=A_{0}+\mathbf{A}_{s}^{\prime} \tilde{\mathbf{s}}_{t}+\mathbf{A}_{x \perp}^{\prime} \tilde{\mathbf{x}}_{\perp, t}+\mathbf{A}_{\delta}^{\prime} \tilde{\boldsymbol{\delta}}_{t}+A_{z} z_{t}
$$


where tildes denote demeaned variables,

$$
A_{z}=-\frac{1-\phi_{z}}{1-\kappa_{1} \phi_{z}}
$$

and where all other coefficients are unchanged from the baseline model of GLL.

The state space representation of the model takes the form

$$
\begin{aligned}
& \mathcal{Y}_{t}=\mathbf{H}_{t}^{\prime} \boldsymbol{\beta}_{t}+\mathbf{b} \\
& \boldsymbol{\beta}_{t}=\mathbf{F} \boldsymbol{\beta}_{t-1}+\varepsilon_{t},
\end{aligned}
$$

where $\mathcal{Y}_{t} \equiv\left(e y_{t}, r_{f t}, p y_{t}, r p_{t}, \Delta y_{t}\right)^{\prime}$ is an observation vector that contains observations on the corporate earnings share of output, the risk-free rate, the price-output ratio, a measure of the equity risk premium implied by options data due to Martin (2017), and corporate output growth. The latent state vector is $\boldsymbol{\beta}_{t} \equiv\left(\tilde{\mathbf{s}}_{t}^{\prime}, \tilde{\boldsymbol{\delta}}_{t}^{\prime}, \tilde{\mathbf{x}}_{\perp, t}^{\prime}, \Delta \tilde{y}_{t}\right)^{\prime}$. If we let $H_{i}$ denote the row/element of $\mathbf{H}_{t}$ corresponding to the log ratio of the stock price to output $\left(p y_{t}\right)$, then the log difference in the stock price according to the model is given by

$$
\begin{aligned}
\Delta p_{t+1} & =\Delta p y_{t+1}+\Delta y_{t+1} \\
& =H_{i}^{\prime} \Delta \boldsymbol{\beta}_{\boldsymbol{t + 1}}+g-\left(1-\phi_{z}\right) z_{t}+\varepsilon_{z, t+1}+\varepsilon_{a, t+1} \\
& =g+H_{i}^{\prime}\left(-(I-\mathbf{F}) \boldsymbol{\beta}_{t}+\boldsymbol{\varepsilon}_{t+1}\right)-\left(1-\phi_{z}\right) z_{t}+\varepsilon_{z, t+1}+\varepsilon_{a, t+1} .
\end{aligned}
$$

GLL estimate the full dynamic model in (2) and (3) using state space methods, allowing us to precisely decompose the market's observed growth into these distinct component sources. The model is flexible enough to explain $100 \%$ of the change in equity values over the sample and at each point in time. To capture the influence of primitive shocks to latent variables at different horizons, we model each as a mixture of multiple stochastic processes driven by lowand high-frequency variation. GLL apply and estimate the model using data on the U.S. corporate sector over the period 1952:Q1-2017:Q4, where their focus is on understanding why stocks relative to measures of aggregate economic activity have risen so much over the post-war period.

Here we are interested understanding stock market behavior in the COVID-19 economic crisis. To address this episode, we first update the data with observations through 2019:Q4. 
We then decompose the growth in the market equity values for the corporate sector into sources attributable to different latent components. This is accomplished by either fixing one component during a particular period, or by allowing only one component to vary.

We begin by asking what factors could have plausibly driven the sharp decline in stock market values $\Delta p_{t+1}$ in 2020:Q1. For this we need to fill in the terms of (4). This is accomplished by replacing the the time- $t$ latent state vector $\boldsymbol{\beta}_{t}$ with its estimated value $\boldsymbol{\beta}_{t \mid t}$ for 2019:Q4 assuming that $z_{t}=0$ prior to the arrival of the COVID-19 shock, yielding

$$
\Delta p_{t+1}=g-H_{i}^{\prime}(I-\mathbf{F}) \boldsymbol{\beta}_{t \mid t}+H_{i}^{\prime} \varepsilon_{t+1}+\varepsilon_{z, t+1}+\varepsilon_{a, t+1} .
$$

Since the model decomposition is expressed in logs, the observed decline in the stock market between February 19 and March 23 of $33.7 \%$ in levels converts to log market equity growth of $\Delta p_{t+1}=\log (1-0.337)=-0.414$. We may then ask which combinations of shocks could plausibly explain this sharp decline, where our candidate set includes the transitory COVID-19 output shock $\varepsilon_{z, t+1}$, the permanent output shock $\varepsilon_{a, t+1}$, and the remaining shocks contained in $\varepsilon_{t+1}$, which include shocks to both low- and high-frequency components of the corporate earnings share, $s_{t}$, of real interest rates, $r_{f, t}$, and of the orthogonal price of stock market risk $x_{\perp, t}$.

Unlike the other elements of $\varepsilon_{t+1}$, we specify the transitory COVID-19 output shock $\varepsilon_{z, t+1}$ as a one-time event rather than estimating it from the data in each period. We do this to account for the fact that this shock to the macroeconomy appears to be of a unique scale following the outbreak of COVID-19, and therefore would not be well approximated by a Gaussian process with constant volatility in all periods. We therefore need to calibrate, rather than estimate, the size of this shock to output, as perceived by market participants in real time. To obtain a measure of this object, we consult the Survey of Professional Forecasters (SPF). The May 2020 wave of this survey indicates a median forecast of $-32.2 \%$ annualized growth in 2020:Q2, which is quite close to what the Bureau of Economic Analysis "advance" estimate of $-32.9 \%$ turned out to be when it was released on July 30, 2020. The annualized decline of $32.2 \%$, once converted to a quarterly growth rate in logs is

$$
\varepsilon_{z, t+1}=0.25 \cdot \log (1-0.322)=-0.0972 \text {. }
$$


Because asset prices are forward looking, the impact of this shock on the value of the stock market depends not only on this shock size, but also its persistence, governed by $\phi_{z}$. Since $z_{t}$ is modeled as an $\operatorname{AR}(1)$ process, the expected growth rate in the period following the shock is given by

$$
\mathbb{E}_{t+1} \Delta z_{t+2}=-\left(1-\phi_{z}\right) \varepsilon_{z, t+1} .
$$

Since the May 2020 wave of the SPF indicates a median forecast of $10.2 \%$ annualized growth in 2020:Q3, equivalent to a quarterly log growth rate of 0.0243 , we can substitute from (6) into (7) and solve to obtain $\phi_{z}=0.741$. This serves as our baseline value for $\phi_{z}$.

With the model now fully specified, we compute model estimates of the implied decline in the market that can be attributed to various sources, displayed in Table 1. To start, we consider the possible role of a transitory COVID-19 output shock $\varepsilon_{z, t+1}$ of size -0.0972, holding fixed all other shock elements in $\varepsilon_{t+1}$. The results for the baseline value of $\phi_{z}$ are presented in the first column of the table, and show that a transitory shock of this magnitude and persistence implies log market equity growth of $\Delta p_{t+1}=-0.0015$, explaining a mere $0.37 \%$ of the actual $\log$ growth $\Delta p_{t+1}=-0.411$. Despite the extreme severity of the projected decline in aggregate economic activity by a magnitude that would eclipse any quarter of the Great Depression in the United States, it is just too transitory to be an impetus for a major decline in stock market values.

Even if we assume that the an initial shock of the same magnitude were far more persistent, this mechanism is still unable to explain much of the observed decline in the market. For example, if instead of $\phi_{z}=0.74$ we assume $\phi_{z}=0.99$, the decline in output alone implies $\log$ market equity growth of $\Delta p_{t+1}=-0.0347$, explaining only $8.4 \%$ of the observed decline. Even in the limit, a fully permanent shock $\left(\phi_{z}=1\right)$, would yield quarterly market equity growth of $\Delta p_{t+1}=-0.0972$, which is just $23.7 \%$ of the observed decline. These small contributions can be understood because, even under permanent output shocks where shareholder payout falls proportionally with output, once we fix the required rate of return on stocks, the growth in the value of market equity can be at most as large as the output growth shock $\varepsilon_{z, t+1}$. Since the observed decline in the market between February 19 and March 23rd was $33.7 \%$ while the expected quarterly decline in output for 2020:Q2 was only $9.7 \%$, the direct 
contribution of changes in output alone to the observed market decline is quite limited.

Next we consider what can be explained when the same baseline transitory $\left(\phi_{z}=0.74\right)$ output drop is accompanied by a decline in the corporate earnings share of various magnitudes, as measured by the standard deviation of the shock to either the low- or high-frequency component of the corporate profit share. The combined effects when the decline in the profit share ranges from one to five standard deviations are reported in columns 2 through 6 of Table 2, with those for the low-frequency component reported in the first row, and those for the high-frequency component reported in the second row. The table shows that combining a large transitory output drop with a drop in the corporate earnings share of output can explain a larger market drop, but the magnitudes are still much smaller than the observed log growth of -0.411. Explaining the full drop with these combined sources of variation would require either a 0.231 (14.2 standard deviation) decline in the log low-frequency component of the earnings share on top of the transitory drop in output, or a 1.445 (27.0 standard deviation) decline in the log high-frequency component.

While log declines on the order of 0.231 have occurred in the total log earnings share over our sample, such as a decline of 0.234 in 2008:Q4, these declines occur during economic downturns and result in highly transitory movements in the earnings share. In particular, they typically revert quickly. For example, Figure 1 shows that the level of the earnings share dropped precipitously early on in the Great Recession, but quickly reversed itself and exceeded its pre-recession level before the recession had ended. (The labor share exhibits the mirror image of this trajectory.) This suggests that the only credible source of variation in the corporate earnings share in the COVID-19 recession would need to be a shock to the high-frequency component of the earnings share, which is far more transitory than the trend-like movements captured by the low-frequency component. But explaining the market decline using this high-frequency component would require a 1.445 log drop in the earnings share, more than six times larger than any decline observed in post-war U.S. data.

Taken together, these results suggest that economic fundamentals alone, in the form of a large drop in aggregate output, even if accompanied by a substantial decline in the corporate earnings share of output, are an unlikely force for explaining the early declines in the stock market during the COVID-19 recession. Given that interest rates did not move 
by large magnitudes in a direction that would be commensurate with a drop in stock prices (they were initially mostly unchanged before sharply declining in 2020:Q1), that leaves only the pricing of equity market risk, driven by the orthogonal risk-price factor $x_{\perp, t}$, as the compensating variable to explain the market decline.

It is even more challenging to explain the market turnabout that began on March 24th without appealing to large fluctuations in discount rates, driven by changes in how risk was priced. Neither expected fundamentals nor the quantity of risk appear to have improved in late March and early April. If anything, market expectations of future cash flows further deteriorated around that time (Gormsen and Koijen (2020)), and macroeconomic uncertainty sharply increased between March and April. ${ }^{3}$

While risk-free interest rates are not plausible candidates for explaining the drop in stock prices, they move in a direction that could in principle explain the rebound. On March 3, 2020 the Federal Reserve lowered its target range for the federal funds rate by half a percentage point to 1 to 1.25 percent, and then on March 15, 2020 lowered it again to a range of 0 to 0.25 percent. Since our model incorporates interest rates as a driver of the value of market equity, we can quantify the direct effect of this drop in rates.

Although our model is based on changes in the real rate, we can conservatively approximate the effect of policy through changes in the nominal 3-month treasury rate, since inflation is typically low in recessions, and appears to be so again in this episode. ${ }^{4}$ This rate dropped from an average of $1.53 \%$ over the period November 2019 to February 2020, to an average of $0.14 \%$ over the period April 2020 to July 2020. At the same time, it is not clear how much of this drop should be attributed to the high-frequency versus low-frequency component of interest rates. We therefore bound the explanatory power by considering the response if $100 \%$ of the drop in interest rates occurred in one component or the other. Attributing all of the drop to the high-frequency component would imply a rise in log market equity of $\Delta p_{t+1}=0.0078$, undoing only $1.91 \%$ of the market's initial crash. Attributing all of the drop to the low-frequency component would imply $\Delta p_{t+1}=0.0439$, undoing a larger

\footnotetext{
${ }^{3}$ See the June vintage of the JLN macroeconomic uncertainty (Jurado, Ludvigson, and Ng (2015)) at www.sydneyludvigson.com.

${ }^{4} \mathrm{PCE}$ inflation fell at a $1.89 \%$ annual rate in 2020:Q2.
} 
$10.6 \%$ of the original market crash, but still falling far short of explaining the full recovery in equity values.

To summarize, neither the staggering quarterly decline in economic output for 2020:Q2, nor reasonable expectations for the corporate profit share of output or short-term interest rates are plausible candidates for explaining the $\mathrm{V}$-shaped trajectory of the stock market between February and April of 2020 according to the model estimates. We are left with only one other major factor that could explain the market behavior, namely independent variation in the stock market risk premium resulting from sharp fluctuations in the pricing of stock market risk $x_{\perp, t}$. This may seem surprising given that many commentators have attributed the market busts in recessionary episodes to the shrinking economy, and the booms to sharp declines in risk-free interest rates. Yet the timing and magnitude of fluctuations in the market during this episode do not align with the fluctuations in economic fundamentals, leaving an important role for rapidly fluctuating attitudes toward risk or investor sentiment in driving the pricing of stock market risk early in 2020. The question then becomes, why did attitudes shift so abruptly? The next section explores the possible role of the Federal Reserve actions in response to the coronavirus in possibly shoring up risk tolerance and contributing to strong stock market rebound in late March and April of 2020.

\section{The Role of the Fed: An Event Study}

This section describes the high-frequency event study of the stock market's behavior in the U.S., in the minutes surrounding Federal Reserve (Fed) communications in March and April of $2020 .^{5}$ We are particularly interested in how announcements pertaining to new credit facilities, unprecedented in both scope and magnitude, may have affected the stock market. We are also interested in contrasting the effects of announcements regarding the creation of new credit facilities with more traditional FOMC announcements on target ranges for the federal funds rate and large scale asset purchases, since the latter are more directly related to the risk-free rate component of the discount rate used for stock market valuation. This

\footnotetext{
${ }^{5}$ For a related study of Federal Reserve actions on the corporate bond market, see Haddad, Moreira, and Muir (2020).
} 
separation will help us distinguish the roles of short rates versus risk premia in driving the market rebound.

\subsection{Federal Reserve Actions in Response to COVID-19}

In a series of announcements in March and April of 2020, the Fed outlined the parameters of several new credit facilities created to address the economic fallout from the coronavirus pandemic, in addition to communicating about the expansion of credit provided by existing facilities first created during 2008 financial crisis. In addition, there were several more conventional Federal Open Market Committee (FOMC) announcements giving the outlook for the economy, new target ranges for the federal funds rate, or new large scale asset purchases. A complete summary of these announcements and their main content can be found in the Appendix.

On March 3 at 10:00am and March 15 at 5pm, the Federal Reserve released FOMC statements outlining conventional monetary policy steps to address the slowing economy by lowering the target range for the federal funds rate, and increasing its holdings of Treasuries and agency mortgage backed securities (MBS). On April 29 at 2:00pm, the Fed released an FOMC statement declaring that it would continue to purchase Treasury securities and agency MBS. We refer to these as "conventional" monetary policy announcements.

Next came a series of announcements stating that the Fed would revive and/or expand credit facilities similar to those created during the 2008 financial crisis. These include a commercial paper funding facility (CPFF, announced March 17 at 10:45am) a primary dealer credit facility (PDCF, announced March 17 at 6:00pm), a Money Market Mutual Fund Liquidity Facility (MMLF, announced March 18 at 11:30pm), and facilities to support dollar swap lines with other Central Banks (March 19 at 9:00am and March 20 at 10:00am). With the exception of the PDCF, we shall refer to these events as "unconventional" monetary policy announcements, albeit using pre-existing facilities. The PDCF was created to support funding to primary dealers, who are trading counterparties of the Federal Reserve Bank of New York in its implementation of conventional monetary policies to alter or maintain target 
ranges for the federal funds rate. ${ }^{6}$ For this reason, we classify it as a "conventional" monetary policy announcement.

On March 23 of 2020 the Federal Reserve began the first of several communications on the creation more credit facilities that were entirely new to the COVID-19 crisis. These include the creation of the Primary Market Corporate Credit Facility (PMCCF, March 23 at 8:00am), the Secondary Market Corporate Credit Facility (SMCCF, March 23 at 8:00am), the Term Asset-Backed Securities Loan Facility (TALF, March 23 at 8:00am), as well as expanding the scope of the MMLF and CPFF (March 23 at 8:00am). These were followed by announcements foreshadowing the creation of the Paycheck Protection Program Loan Facility (PPPLF, April 6 at 2:00pm), an announcement on April 9 at 8:30am that the Fed would take additional action to provide up to $\$ 2.3$ trillion in loans to support the economy. The April 9 communication also announced measures to bolster the PPPLF, to create the Main Street Lending Program (MSLP) and the Municipal Liquidity Facility (MLF), and to expand the size and scope of the PMCCF, SMCCF, and TALF. On April 23 at 5:45pm, the Fed announced the future expansion of the PPPLF; on April 27 at 4:30pm it announced an expansion of the scope and duration of the MLF; and on April 30 at 10:00am it announced the expansion of the scope and eligibility of the MSLP. We shall classify all of these announcements as "unconventional" monetary policy announcements.

The months of March and April of 2020 were clearly characterized by a tremendous volume of fast-evolving news about the coronavirus disease 2019 and the resulting economic fallout. The minutes bracketing at least some of Federal Reserve policy announcements are therefore likely to have coincided with other pieces of news about the pandemic that could have predominated as a causal factor in market fluctuations, especially if the announcement occurred outside of U.S. trading hours. We address this in two ways. First, where possible, we focus on narrow 30-minute windows around a Fed announcement to measure the market

\footnotetext{
${ }^{6}$ The Primary Dealer Credit Facility (PDCF) is a loan facility that will provide credit to primary dealers in exchange for a broad range of collateral for term funding with maturities up to 90 days. The stated purpose of the PDCF is to support the credit needs of American households and businesses by fostering the functioning of financial markets more generally and to expand the ability of primary dealers to gain access to term funding.
} 
impact of the announcement, and otherwise-if the announcement occurred outside of trading hours- we use the most recent closing price and the 20-minutes after the subsequent opening price. Second, we augment our understanding of the most important pieces of market news surrounding a given announcement by conducting a systematic analysis of a newspaper reports from FACTIVA.

Figures 3 and 4 display the intra-day movements in the S\&P 500 stock market index in 30-minute windows around a given Fed announcement, where Figure 3 shows the movements for the conventional monetary policy announcements, and Figure 4 shows those for what we have defined as unconventional monetary policy announcements. ${ }^{7}$

What is immediately clear from examining both figures is that not all announcements of Fed actions to address the economic costs of COVID-19 were associated with a rise in the stock market. For the conventional monetary policy announcements, Figure 3 shows that, with the exception of the March 3 FOMC statement, all of those announcements are associated with a decline the market in the minutes immediately subsequent to it. In the case of the March 15 announcement, the lowering of the target range for the federal funds rate to 0 to $1 / 4$ percent seems to only have amplified worries over the extent of the damage from the pandemic, according to news reports. The action to create the PDCF to support liquidity to the New York Federal Reserve Bank's trading counterparties, announced March 17 at 6:00pm, seems to have been largely ignored by market commentators in news reports. Finally, the FOMC statement on April 29th at 2pm that the Fed would continue to purchase Treasury securities and agency MBS is associated with a brief increase in the market immediately thereafter, but it failed to sustain, with all the gains being lost within 20 minutes. Of course, if the expectation of the March 15 th rate cut to zero had already been priced in at the time of that announcement, the market turnabout on March 23 is all the more puzzling, since in that case lower risk-free rates cannot be offered to help explain it.

Among the unconventional monetary policy announcements, there are at least four for which there is little to no evidence that they either were the impetus for a market rally. Two

\footnotetext{
${ }^{7} \mathrm{~A}$ spreadsheet tracking the news around the announcements is available upon request.
} 
of these appear to have been preponderated by bad news about the virus. Figure 4 shows that neither news of the creation of the MMLF on March 18 at 11:30pm, nor news of the creation of three new facilities and the expansion of two others on March 23 at 8:00am, are associated with a significantly higher opening price for the S\&P 500 subsequently. For the March 18th event, news reports hinted at a disappointment over the eligibility of assets under the MMLF and restrictions on their maturity. For the March 23rd event, news reports on the market reaction expressed a belief that the Fed's actions would be insufficient in the absence of additional fiscal support. ${ }^{8}$ Figure 4 shows that the announcement at $2 \mathrm{pm}$ on April 6 th of the creation of a facility to provide term financing backed by paycheck protection program (PPP) loans was likewise not associated with a rise in the market. News reports here suggested that the PPP program had been functioning poorly and that this step by the Federal Reserve had been widely anticipated prior to the announcement. The poor functioning of the program could also explain why the two subsequent announcements related to the PPP, one on the future expansion of the PPPLF (April 23 at 5:45pm) and the announcement inaugurating that expansion (April 30 at 5:15pm), also failed to spark a sustained market rise. In the case of the announcement on April 23, the market was higher at the opening bell on the 24 th, but the increase failed to sustain. The April 30th announcement appears not to have contained any real news, given that the future expansion of the PPPLF had previously been announced on April 23rd.

So which announcements of actions taken to support the economy, if any, aided the stock market? To gauge the effect of an announcement, we follow prior research (e.g., Guraynak, Sack, and Swanson (2005)) and consider a measurement window that begins 10 minutes prior to a Fed announcement and ends 20 minutes after the announcement, unless the announcement occurred outside of trading hours, in which case we use the most recent closing price and the price 20 minutes after the opening bell on the next day. Given windows of this length, Figure 4 suggests that five separate announcements in March and April are candidates for bolstering the stock market: March 17 at 10:45am, March 20th at 10:00am, April 9th at 8:30am, April 27th at 4:30pm, and April 30th at 10:00am. While the figure is

\footnotetext{
${ }^{8}$ In contrast to the stock market reaction, Haddad, Moreira, and Muir (2020) find that the March 23rd announcement generated a $6 \%$ return on investment grade corporate debt at the time of the announcement.
} 
suggestive, it is unclear how much quantitative support for the market these announcements actually provided. To address this question, we turn to a regression analysis.

\subsection{Regression Analysis}

We consider a data sampling interval of 10 minutes and examine stock market changes in 30-minute windows surrounding a Fed announcement, or "event." We then formally test whether stock market price changes in these 30-minute announcement windows are different from those in non-announcement windows. Specifically, let $t$ denote a 10-minute interval during the trading day. We construct 30-minute returns as follow

$$
\Delta p_{t-1, t+2}=\ln \left(\frac{P_{t+2}}{P_{t-1}}\right) \times 100,
$$

where $P_{t}$ is measured as the beginning of interval price, i.e., if the interval spans 9:30am to 9:40am, the price is measured at 9:30am.

Let $N$ denote the total number of Fed events in our sample and let $j$ index a particular event, i.e., $j=1, \ldots, N$. Then $D_{t}^{j}$ denotes a dummy variable that takes the value 1 if event $j$ occurred at time $t$ and 0 otherwise. We regress the 30 -minute changes in the stock market price on the sum of $2 N$ dummies:

$$
\Delta P_{t-1, t+2}=\beta_{0}+\sum_{j=1}^{N} \beta_{1}^{j} D_{t}^{j}+\sum_{j=1}^{N} \beta_{2}^{j} D_{t+1}^{j}+\epsilon_{t} .
$$

In the above, $D_{t}^{j}$ is a dummy that selects the 10-minute interval in which the announcement occurred, while $D_{t+1}^{j}$ is a dummy that selects the 10-minute interval immediately after the announcement interval. For events that occur during market trading hours, the left-handside variable is the log difference between the price 20 minutes after and 10 minutes before the event. For events that occur outside of trading hours, the left-hand-side variable is the log difference between the price 20 minutes after the market opens on the first trading day after the announcement, and the most recent closing price. The regression is estimated on 10-minute data from January 1 to May 5 of 2020 using Ordinary Least Squares (OLS) with heteroskedasticity robust standard errors. F-statistics for testing whether the sum of coefficients on the two dummies for a given event $j$, i.e. $\sum_{k=1}^{2} \beta_{k}^{j}$, and for all events $j$, i.e., $\sum_{j=1}^{N} \sum_{k=1}^{2} \beta_{k}^{j}$ are different from zero, are reported below. 
Table 3 presents the results of regression 8 on dummies for the unconventional and conventional monetary policy announcements separately. The table reports the sum of the coefficients on the two dummies for each event $j$ in individual rows, as well as for all $j$ at the bottom of the table. In this table we report results for a specification that uses nine unconventional monetary policy announcements (left panel), listed by their day and time, including the four discussed above that are associated with a decline in the market over the 30-minute window surrounding the announcement. The right panel reports results for a specification on the four conventional monetary policy announcements discussed above.

The right panel shows that there is no evidence that the conventional monetary policy announcements were collectively a source of support for the stock market. Indeed, the sum of the coefficients on the dummies for conventional monetary policy actions is -17 in a regression where the dependent variable is the log difference in the S\&P 500 stock market index. This implies that the conventional announcements are collectively associated with a decline of approximately $17 \%$ in the stock market. A reading of news reports suggests that these negative "effects" likely reflect the market participants' asessment that conventional monetary policy actions would be inadequate by themselves, rather than an asessment that the actions per se would be harmful.

The left panel of Table 3 quantifies the market's reaction in the 30-minute windows surrounding the unconventional monetary policy announcements, with the total effect summing across events that were both supportive and unsupportive. The sum across all coefficients on the unconventional policy announcement dummies is 1.53 for the S\&P 500, implying that when taken together, these events provided only modest support for the market. The numbers for the Nasdaq and Russell 2000 are larger, equal to 3.64 and 6.98 respectively. As discussed above, however, there is reason to believe that four of these announcements were either overshadowed by other negative related to the pandemic, or instead their content was widely anticipated and not an important piece of news. In order better isolate the effects of announcements that could have sparked a stock market gain, we run a separate specification in which dummies are included only for the five events discussed above that appear to have contributed to a market rebound in the S\&P 500 index.

Table 4 presents these results. Collectively, these five announcements are associated with 
gains of approximately $8.3 \%$ in the S\&P 500 stock market index and $12 \%$ in the Russell 2000 index. Among all these unconventional policy announcements, the communication on April 9th at 8:30am, in which the Fed announced it would take additional steps to provide up to $\$ 2.3$ trillion in loans to support the economy, is estimated to have the largest effect, followed closely by the announcement on March 17 at 10:45am on the creation of the CPFF. The former is associated with an approximately $3 \%$ increase in the market, and the latter a $2.65 \%$ increase.

To summarize, while still leaving a large portion of the market recovery that began on March 24th of 2020 to be explained by other factors, points to a substantial role for the Federal Reserve, especially with its creation of new lending facilities, in pushing the stock market upward. By the third week of August of 2020, the market had risen further and several indexes had risen to all-time highs. With the benefit of hindsight, we can now observe how much credit the Federal Reserve has actually extended under these new facilities. In particular, we can assess how much of the $\$ 2.3$ trillion in loans to support the economy that the Federal Reserve announced on April 9 that it stood ready to provide has actually been extended. If that amount is close to the $\$ 2.3$ trillion amount pledged, then the role these announcements appear to have played in the market turn-around might reasonbly be described as a rational response to an important piece of good news.

\subsection{How Much Credit Has Been Extended?}

One piece of information on the credit actually extended is the Federal Reserve's balance sheet. This information turns out to be noisy, for reasons discussed below. Still, it is useful to consider it as part of the picture. In particular, the Fed resports updates every Wednesday on the value of its total assets (less eliminations from consolidation). Figure 4 shows how those assets have changed from the beginning of 2020 to early August of 2020 . The top panel gives a break-down of total assets into two categories: (i) assets associated with both the expanded and new (circa COVID-19) credit facilities, and (ii) all other assets. The latter are primarily comprised of Treasuries and agency MBS. We observe that total assets have increased sharply starting in March 2020 and continue to rise through July 2020. 
They totaled around seven trillion dollars by August. But that the vast bulk of the increase starting in March came in the form of Federal Reserve holdings of Treasuries, MBS and other traditional balance sheet items. Assets held under new and existing facilities increased by a comparitively small amount.

Next, the middle panel of Figure 4 breaks down the change in assets associated with the expanded and new credit facilities. We see that the vast bulk of the increase in these items is attributable to repos, currency swamps, and other Fed assets acquired in their dollar liquidity arrangements with other central banks. The third panel of Figure 4 breaks down the change in assets associated with only the new credit facilities created this year in response to COVID-19. Here the biggest increases have been in the PPPLF, the PMCCF, and the SMCCF. By August, total assets held under all new credit facilities was approximately $\$ 200$ billion.

The assets on the Federal Reserve Balance sheet for a given lending facility are not, however, the same as the dollar value of credit actually extended to the public under the facility. That's because the Treasury puts up capital in a first-loss position in a special purpose vehicle, which gets reported as a liability of the Federal Reserve even if no loan is made. The corresponding asset on the Federal Reserve's balance sheet is the cash deposited by the Treasury as the capital injection. ${ }^{9}$ To see the actual amount of credit extended under the each new facility, we refer to the Federal Reserve's periodic report to Congress delivered on August 8, 2020. ${ }^{10}$ From this report we observe that, as of July 31 of 2020, the MSLP, for example, had total outstanding loans of only $\$ 87.6$ million, even though the total value of the collateral pledged to secure these loans-the number that appears on the Federal Reserve's balance sheet for this facility-was $\$ 37.6$ billion.

Figure 5 decomposes the value of credit actually extended to the public as of July 31 of 2020 by lending facility. The total dollar value of loans extended across all facilities established in response to COVID-19 sums to $\$ 101$ billion, with the vast majority of that

\footnotetext{
${ }^{9}$ We are grateful to Seth Carpenter for help interpreting the accounting of the Federal Reserve's balance sheet.

${ }^{10}$ The report is online at https://www.federalreserve.gov/publications/files/nonlf-noelf-pdcf-mmlf-cpffpmccf-smccf-talf-mlf-ppplf-msnelf-mself-msplf-8-10-20.pdf\#page $=5$
} 
( $\$ 70.7$ billion) attributable to the PPPLF. This is followed by the MMLF ( $\$ 13.7$ billion), the PMCCF+SMCCF ( $\$ 12$ billion), TALF ( $\$ 1.6$ billion), MLF ( $\$ 1.2$ billion), the PDCF (\$0.3 billion), the CPFF (\$0.1 billion), and finally the MSLF ( $\$ 0.087$ billion). These dollar amounts are tiny when compared to a roughly $\$ 19$ trillion dollar real GDP flow in 2019, but are even small relative to the several trillion in loans that the Federal Reserve announced it stood ready to provide on April 9th.

Overall, these results suggest that the Federal Reserve played a direct role in the market turnabout. But it did so not with a substantive extension of dollars to support the economy. Moreover, there is little evidence that traditional monetary policy steps were the impetus for a market rally, at least initially. This evidence suggests that the Federal Reserve has important effects the stock market by altering market participants' willingness to bear stock market risk, independently of any role it plays in macroeconomic dynamics. The findings reinforce the conclusions of our estimated asset pricing model, which point to a major role for fluctuations in effective risk aversion or sentiment in driving stock market volatility between February and April of 2020.

\section{Conclusion}

This study investigates the role of different causal factors in driving the sharp V-shaped trajectory of the U.S. stock market in the early stages of COVID-19. The S\&P 500 stock market index lost 33.7\% of its value between February 19 and March 23rd of 2020, but abruptly regained the vast majority of this lost value, rising $29 \%$ between March 24 th and April 17. At the time of this writing, most market indexes have now surpassed their previous records set in the pre-COVID-19 era.

We find that the most likely candidate for explaining the market's volatility during the early months of the pandemic is the pricing of stock market risk, driven by big fluctuations in risk aversion or sentiment unrelated to economic fundamentals or interest rates. Our conclusions are based both on an estimated asest pricing model and empirical evidence on the role of Federal Reserve communications in March and April of 2020.

We first use the estimated asset pricing model to decompose the market's sharp decline 
into component causal forces. According to the model estimates, neither the highly anticipated staggering quarterly decline in economic output for 2020:Q2, nor reasonable expectations for the corporate profit share of output or short-term interest rates can explain the V-shaped trajectory of the stock market between February and April of 2020. These estimates further imply that the decline to near-zero interest rates in mid-March could explain at most a third of the market rebound. This leaves the most important causal role for rapidly fluctuating attitudes twoard risk or investor sentiment that are independent of the aggregate economic state.

We then explore the possible role of Federal Reserve actions in response to COVID-19 in shoring up risk tolerance and contributing to stock market rebound in late March and April of 2020. Using a high-frequency event study, we find no evidence that "conventional" monetary policy announcements promulgating decisions to lower the target range for the federal funds rate to near zero, or to increase the Federal Reserve's holdings of Treasury securities and agency MBS were a contributing factor in the market rebound. Conversely, we find that five "unconventional" policy announcements between March 17 and April 30th about new credit facilities collectively contributed to an approximately $8 \%$ higher value for the S\&P 500 index and an approximately 12\% higher value for the Russell 2000. As of July 31 of 2020, however, the dollar value of loans actually extended under the new facilities falls far short of what the Federal Reserve announced it stood ready to provide on April 9th. These results therefore serve to reinforce the conclusion from the estimated asset pricing model, namely that stock market volatility during the coronavirus pandemic has been driven more by sentiment than substance.

\section{References}

Baker, S., N. Bloom, S. J. Davis, and M. Sammon (2019): "What triggers stock market jumps?," Unpublilshed manuscript, Stanford University.

Gormsen, N. J., And R. S. Koijen (2020): "Coronavirus: Impact on stock prices and growth expectations," University of Chicago, Becker Friedman Institute for Economics Working Paper, (2020-22). 
Greenwald, D., M. Lettau, and S. C. Ludvigson (2019): "How the Wealth Was Won: Factors Shares as Market Fundamentals," National Bureau of Economic Research Working Paper No. 25769.

Guraynak, R. S., B. Sack, And E. Swanson (2005): "Do actions speak louder than words? The response of asset prices to monetary policy action and statements," International Journal of Central Banking, 1, 55-93.

Haddad, V., A. Moreira, And T. Muir (2020): "When selling becomes viral: Disruptions in debt markets in the covid-19 crisis and the fedâĂŹs response," Discussion paper, National Bureau of Economic Research.

Jurado, K., S. C. Ludvigson, and S. NG (2015): "Measuring Uncertainty," The American Economic Review, 105(3), 117-1216.

Martin, I. (2017): "What is the Expected Return on the Market?," The Quarterly Journal of Economics, 132(1), 367-433. 


\section{Figures and Tables}

Figure 1: Earnings and Labor Share
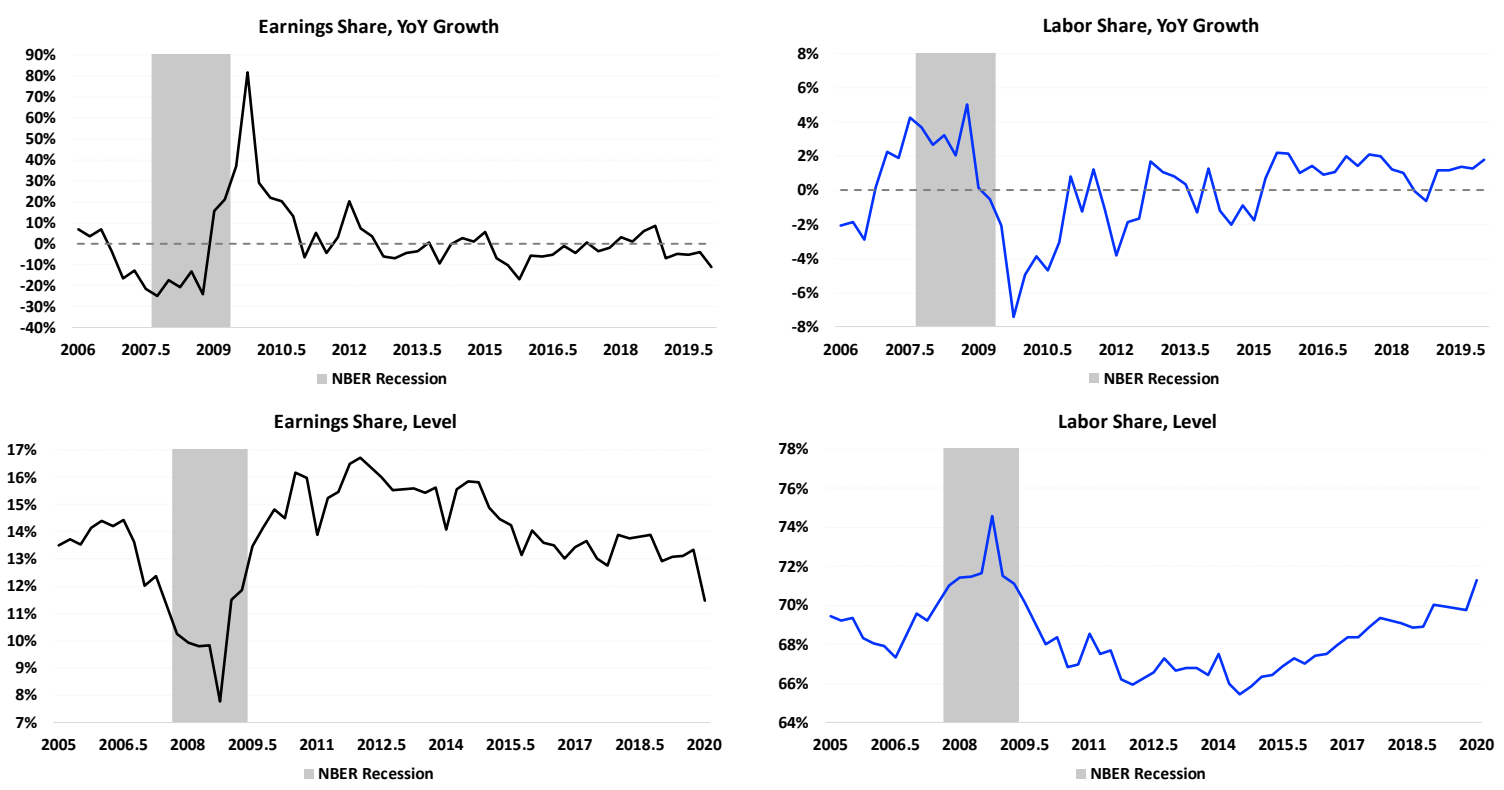

Notes: The earning share is computed as the ratio of after tax profits over the net value added. Labor share is the ratio of labor compensation over the net value added. The sample spans the period 2005:Q1-2020:Q1. 


\section{Figure 2: Intraday S\&P500 Index on Conventional MP Announcement Days}
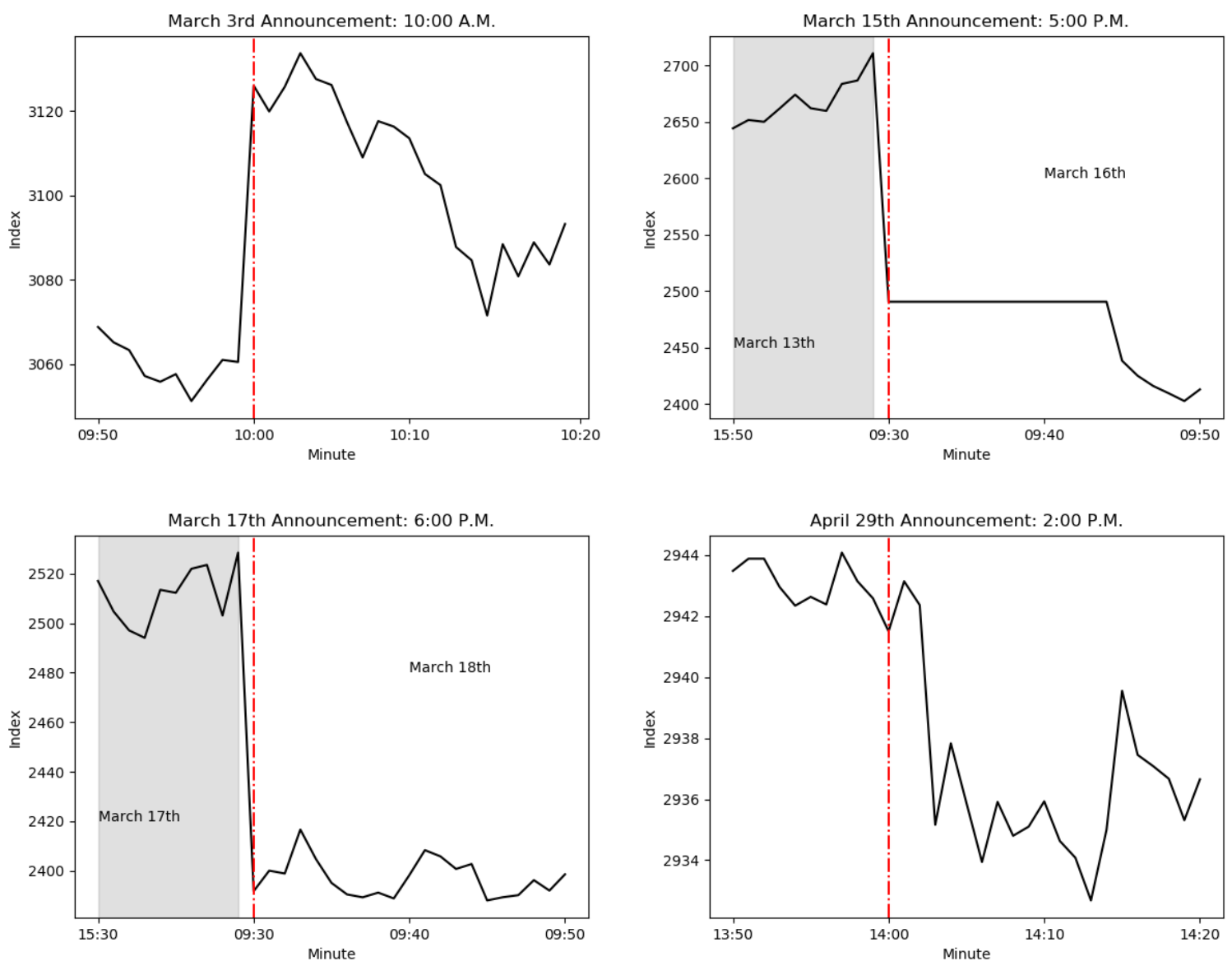

Notes: The figures present intraday graphs using a 90 minute window. We plot stock prices 30 minutes before and 60 minutes after the announcement. When the announcement occurs during trading hours, the red dashed line shows the time of the FED announcement. When the announcement occurs during nontrading hours, the red line is placed at the opening bell of the next trading day. Source: FirstRateData (https://firstratedata.com). 
Figure 3: Intraday S\&P500 Index on Unconventional MP Announcement Days
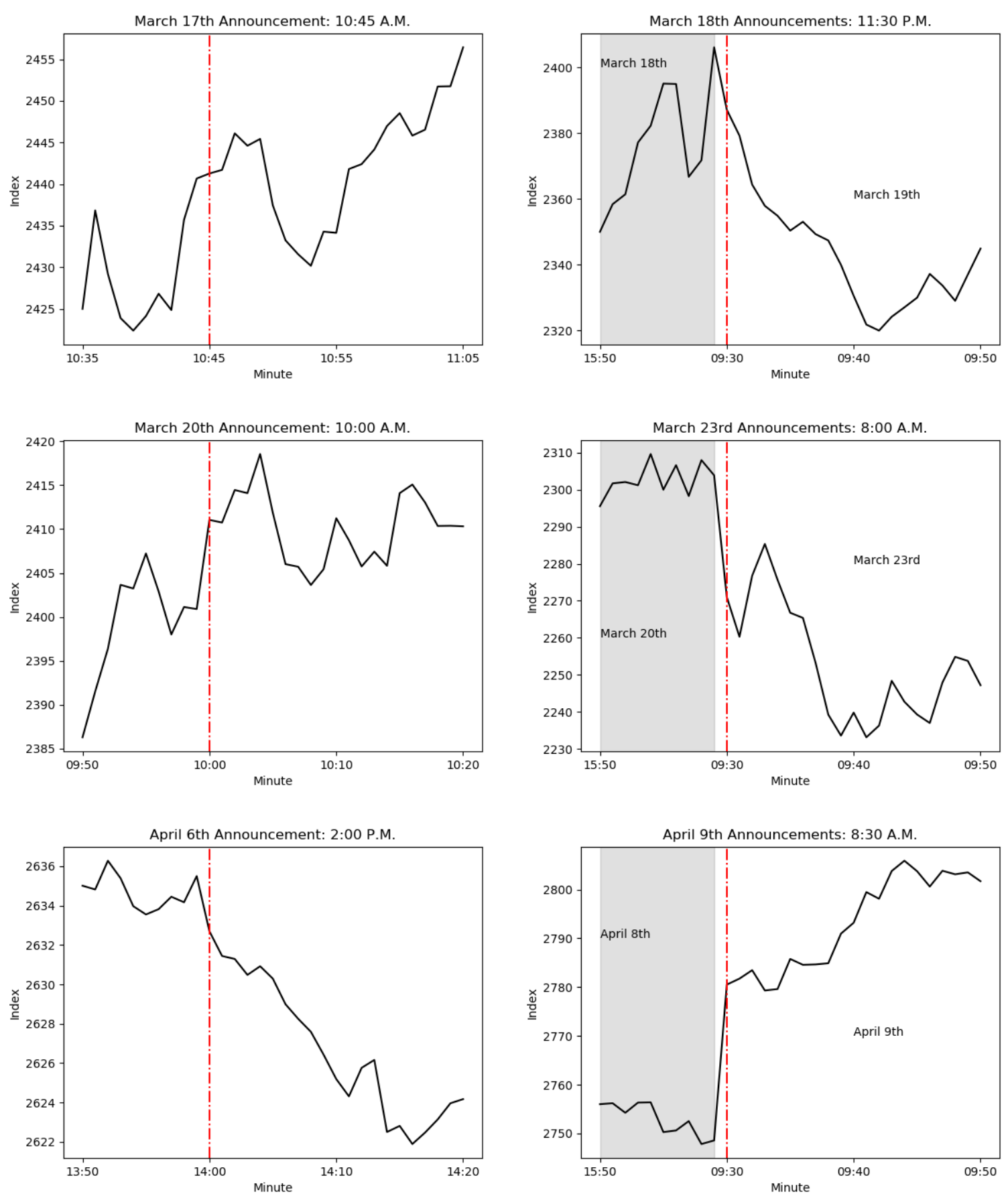

Notes: See notes on the next page. 
Figure 4: Intraday S\&P500 Index on Unconventional MP Announcement Days (continued)
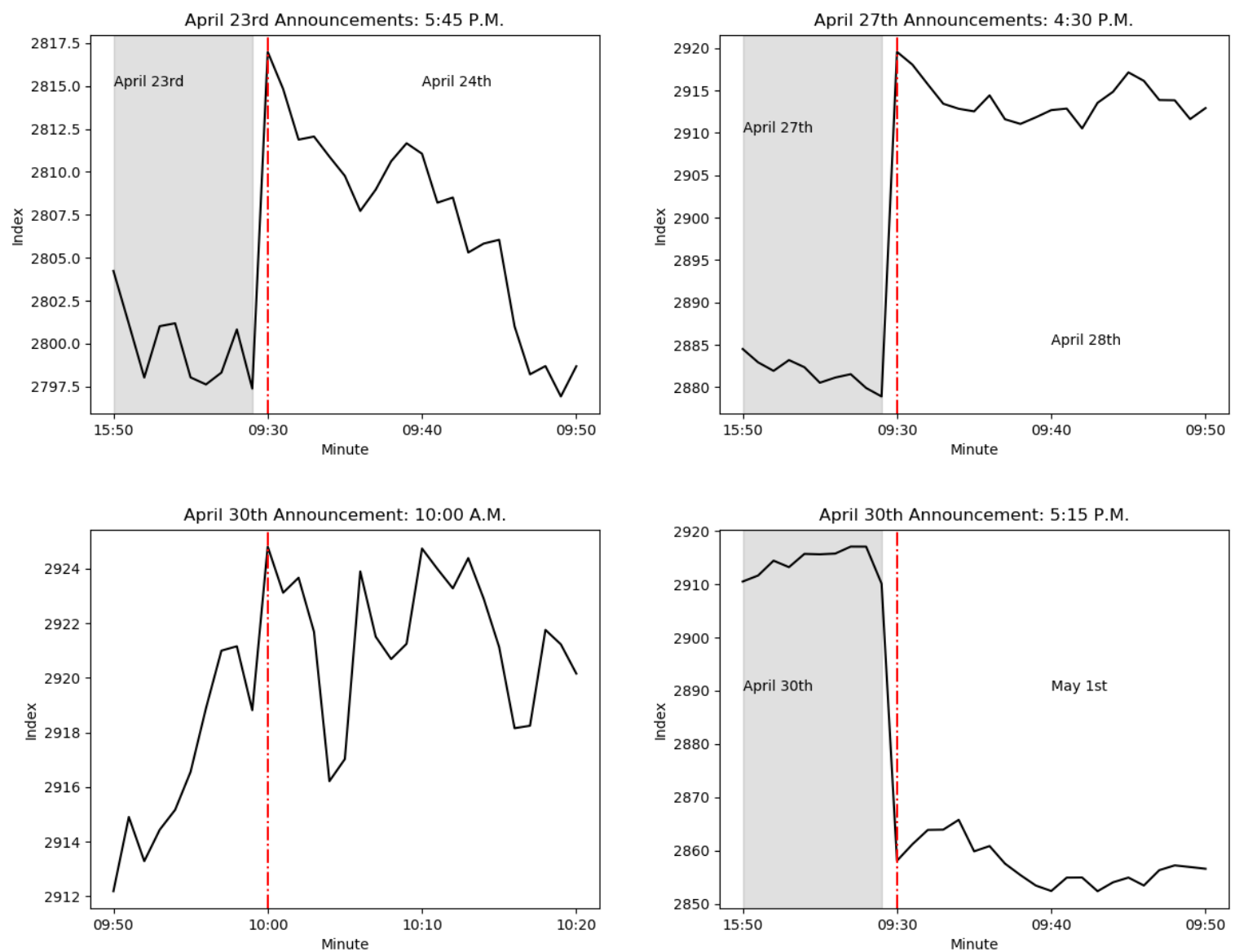

Notes: The figures present intraday graphs using a 90 minute window. We plot stock prices 30 minutes before and 60 minutes after the announcement. When the announcement occurs during trading hours, the red dashed line shows the time of the FED announcement. When the announcement occurs during nontrading hours, the red line is placed at the opening bell of the next trading day. Source: FirstRateData (https://firstratedata.com). 
Figure 4: Federal Reserve Total Assets (less eliminations from consolidation)

(a) Breakdown of Total Assets

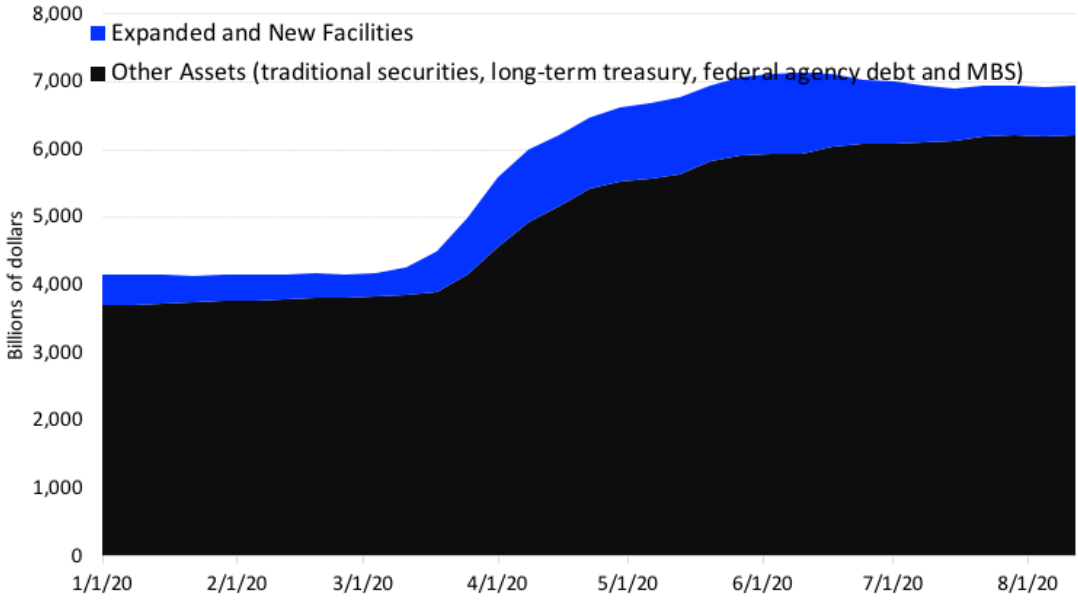

(b) Breakdown of Expanded and New Facilities

1,500

Other assets (Repos, currency swaps, and other Fed assets)

MSLP

MLF

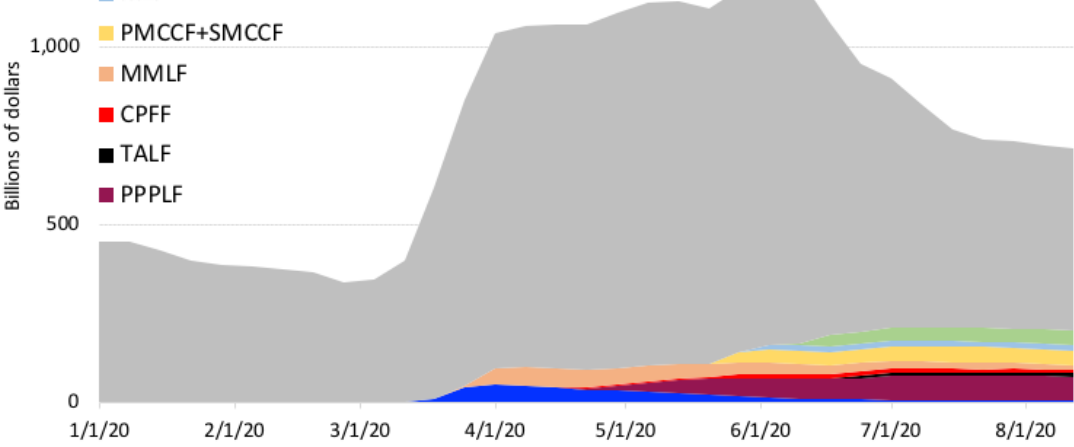

(c) Breakdown of New Facilities

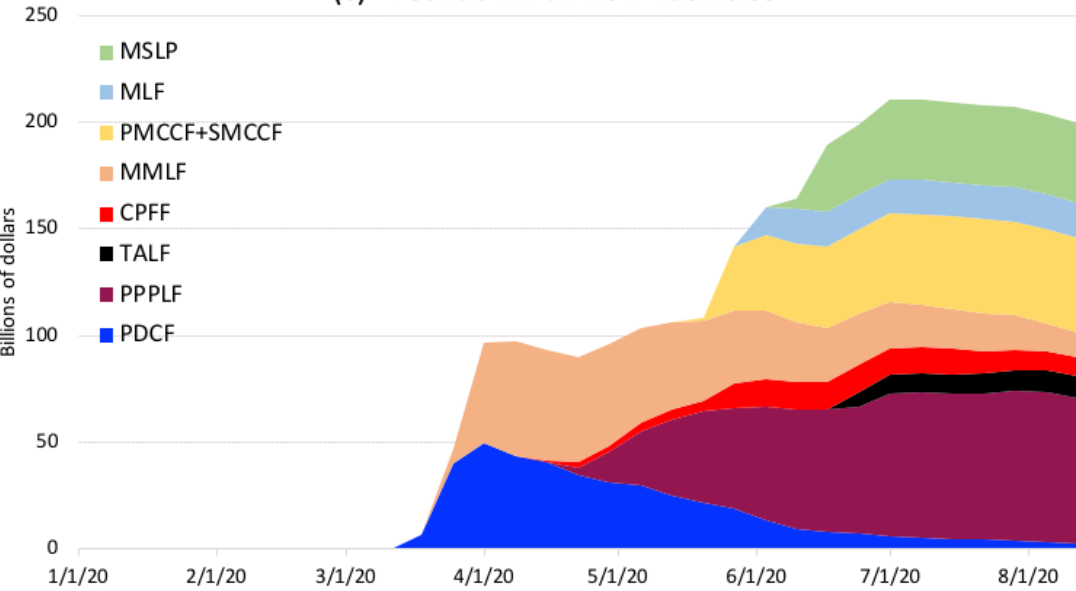

Notes: Panel (a) presents the aggregated FED total assets. Panel (b) presents the main components of the Expanded and New Facilities. Panel (c) presents the new facilities announced during March and April 2020. Source: The Federal Reserve Bank of Cleveland based on data from the Federal Reserve Board and Haver Analytics (https://www.clevelandfed.org/en/ourresearch/indicators-and-data/credit-easing.aspx). 
Figure 5: Total Credit Extended under New Facilities as of July 31, 2020

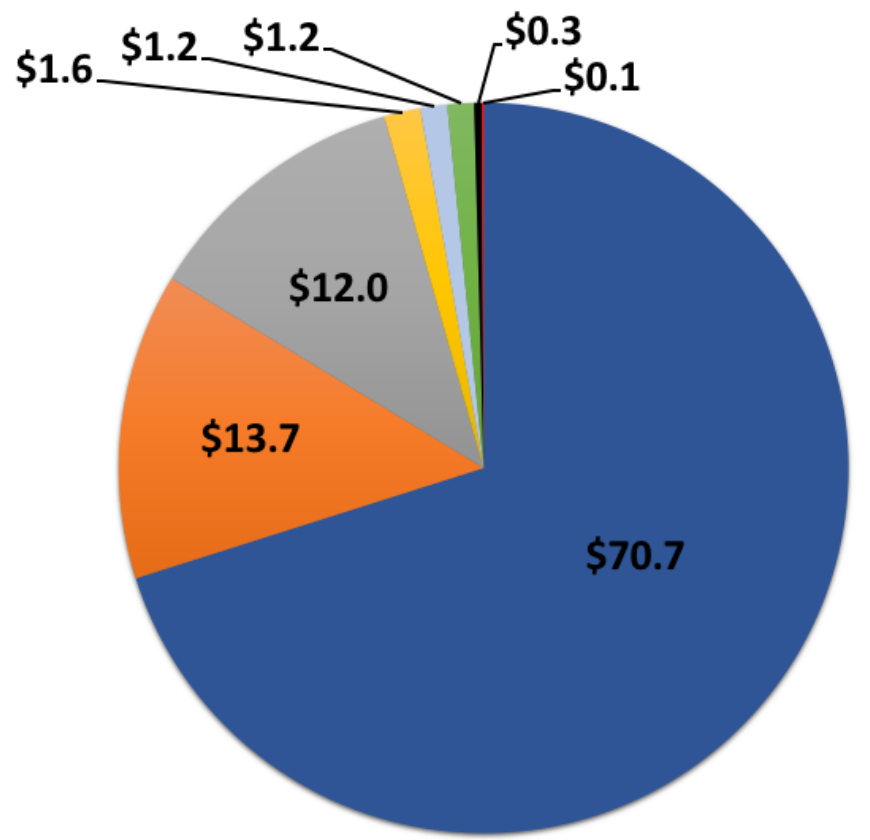

\section{Total Outstanding Credit Extended: \$101 Billion} PPPLF $\square$ MMLF $\square$ PMCCF+SMCCF $\square$ TALF MLF $\square$ PDCF $\square$ CPFF $\square$ MSLP

Notes: The figure presents the actual lending provided by the facilities deployed by the FED as of July 31st, 2020. Source: Federal Reserve Board (https://www.federalreserve.gov/publications/files/nonlf-noelf-pdcf-mmlf-cpff-pmccf-smccf-talf-mlf-ppplfmsnelf-mself-msplf-8-10-20.pdf \#page=5 ) 
Table 1: Model Results: Output Shock Only

\begin{tabular}{lcccc}
\hline \hline Persistence $\left(\phi_{z}\right)$ & 0.74 & 0.80 & 0.85 & 0.90 \\
\hline Implied Log Growth & -0.0015 & -0.0021 & -0.0030 & -0.0047 \\
Fraction of Actual ME \% Log Drop Explained & $0.37 \%$ & $0.52 \%$ & $0.73 \%$ & $1.14 \%$ \\
\hline \hline Persistence $\left(\phi_{z}\right)$ & 0.95 & 0.98 & 0.99 & 1.00 \\
\hline Implied Log Growth & -0.0093 & -0.0209 & -0.0347 & -0.0972 \\
Fraction of Actual ME \% Log Drop Explained & $2.28 \%$ & $5.10 \%$ & $8.44 \%$ & $23.66 \%$ \\
\hline
\end{tabular}

Market Decline Explained by COVID Output Shock. The table reports the model-implied total log drop in the market (first row) that can be attributed to a $9.7 \%$ quarterly decline in output, for various persistences $\left(\phi_{z}\right)$ of the shock given in the column headings. The second row gives the fraction of the observed log decline of -0.414 in the market explained by this shock, according to the model.

Table 2: Model Results: Output and Earnings Share Shock

\begin{tabular}{lcccccc}
\hline \hline Change (SD) & 0 & -1 & -2 & -3 & -4 & -5 \\
\hline$\Delta s_{L F}$ & 0.000 & -0.016 & -0.033 & -0.049 & -0.065 & -0.081 \\
Implied \% $\Delta M E$ & $-1.2 \%$ & $-3.9 \%$ & $-6.6 \%$ & $-9.2 \%$ & $-11.7 \%$ & $-14.1 \%$ \\
$\Delta s_{H F}$ & 0.000 & -0.053 & -0.107 & -0.160 & -0.214 & -0.267 \\
Implied \% $\Delta M E$ & $-1.2 \%$ & $-2.6 \%$ & $-4.0 \%$ & $-5.4 \%$ & $-6.8 \%$ & $-8.2 \%$ \\
\hline \hline
\end{tabular}

Market Decline Explained by Output plus Earnings-Share Shock. The table reports the model-implied total log drop in the market (first row) that can be explained by a $9.7 \%$ quarterly decline in output with a persistence of 0.74 , when it is accompanied by a decline in the corporate earnings share of various magnitudes given in the column heading, as measured by the standard deviation of the earnings-share shock to either the low- or high-frequency component of the corporate profit share. The second row gives the fraction of the observed log decline of -0.414 in the market explained by this combination of shocks, according to the model 
Table 3: Event Study: 10-minute data

\begin{tabular}{|c|c|c|c|c|c|c|c|c|c|}
\hline \multirow[b]{2}{*}{ Event Date } & \multicolumn{4}{|c|}{ Unconventional } & \multirow[b]{2}{*}{ Event Date } & \multicolumn{4}{|c|}{ Conventional } \\
\hline & S\&P500 & DJI & Nasdaq & Russ.2000 & & S\&P500 & DJI & Nasdaq & Russ.2000 \\
\hline $\begin{array}{l}\text { March } 17 \\
\text { 10:45 A.M. }\end{array}$ & $\begin{array}{c}2.65^{* * *} \\
(0.02)\end{array}$ & $\begin{array}{c}2.09^{* * *} \\
(0.03)\end{array}$ & $\begin{array}{c}3.27^{* * *} \\
(0.02)\end{array}$ & $\begin{array}{c}0.67^{* * *} \\
(0.03)\end{array}$ & $\begin{array}{l}\text { March } 3 \\
\text { 10:00 A.M. }\end{array}$ & $\begin{array}{c}0.11^{* * *} \\
(0.02)\end{array}$ & $\begin{array}{c}-0.11^{* * *} \\
(0.02)\end{array}$ & $\begin{array}{c}0.42^{* * *} \\
(0.02)\end{array}$ & $\begin{array}{c}0.92^{* * *} \\
(0.03)\end{array}$ \\
\hline $\begin{array}{l}\text { March } 18 \\
\text { 11:30 P.M. }\end{array}$ & $\begin{array}{c}-3.42^{* * *} \\
(0.02)\end{array}$ & $\begin{array}{c}-4.18^{* * *} \\
(0.03)\end{array}$ & $\begin{array}{c}-0.94^{* * *} \\
(0.02)\end{array}$ & $\begin{array}{c}-0.75^{* * *} \\
(0.03)\end{array}$ & $\begin{array}{l}\text { March } 15 \\
\text { 5:00 P.M. }\end{array}$ & $\begin{array}{c}-13.28^{* * *} \\
(0.02)\end{array}$ & $\begin{array}{c}-12.56^{* * *} \\
(0.02)\end{array}$ & $\begin{array}{c}-15.20^{* * *} \\
(0.02)\end{array}$ & $\begin{array}{c}-15.45^{* * *} \\
(0.03)\end{array}$ \\
\hline $\begin{array}{l}\text { March } 20 \\
\text { 10:00 A.M. }\end{array}$ & $\begin{array}{c}1.79^{* * *} \\
(0.02)\end{array}$ & $\begin{array}{c}1.56^{* * *} \\
(0.03)\end{array}$ & $\begin{array}{c}1.63^{* * *} \\
(0.02)\end{array}$ & $\begin{array}{c}2.22^{* * *} \\
(0.03)\end{array}$ & $\begin{array}{c}\text { March } 17 \\
\text { 6:00 P.M. }\end{array}$ & $\begin{array}{c}-3.90^{* * *} \\
(0.02)\end{array}$ & $\begin{array}{c}-3.94^{* * *} \\
(0.02)\end{array}$ & $\begin{array}{c}-2.12^{* * *} \\
(0.02)\end{array}$ & $\begin{array}{c}-6.90^{* * *} \\
(0.03)\end{array}$ \\
\hline $\begin{array}{l}\text { March } 23 \\
\text { 8:00 A.M. }\end{array}$ & $\begin{array}{c}-2.13^{* * *} \\
(0.02)\end{array}$ & $\begin{array}{c}-1.38^{* * *} \\
(0.03)\end{array}$ & $\begin{array}{c}-0.86^{* * *} \\
(0.02)\end{array}$ & $\begin{array}{c}-2.6^{* * *} \\
(0.03)\end{array}$ & $\begin{array}{l}\text { April } 29 \\
\text { 2:00 P.M. }\end{array}$ & $\begin{array}{c}-0.30^{* * *} \\
(0.02)\end{array}$ & $\begin{array}{c}-0.08^{* * *} \\
(0.02)\end{array}$ & $\begin{array}{c}-0.23^{* * *} \\
(0.02)\end{array}$ & $\begin{array}{c}0.26^{* * *} \\
(0.03)\end{array}$ \\
\hline $\begin{array}{l}\text { April } 6 \\
\text { 2:00 P.M. }\end{array}$ & $\begin{array}{c}-0.66^{* * *} \\
(0.02)\end{array}$ & $\begin{array}{c}-0.54^{* * *} \\
(0.03)\end{array}$ & $\begin{array}{c}-0.69^{* * *} \\
(0.02)\end{array}$ & $\begin{array}{c}-1.29^{* * *} \\
(0.03)\end{array}$ & Constant & $\begin{array}{l}-0.00 \\
(0.01)\end{array}$ & $\begin{array}{l}-0.01 \\
(0.01)\end{array}$ & $\begin{array}{c}0.01 \\
(0.01)\end{array}$ & $\begin{array}{l}-0.02 \\
(0.01)\end{array}$ \\
\hline $\begin{array}{l}\text { April } 9 \\
\text { 8:30 A.M. }\end{array}$ & $\begin{array}{c}3.00^{* * *} \\
(0.02)\end{array}$ & $\begin{array}{c}2.93^{* * *} \\
(0.03)\end{array}$ & $\begin{array}{c}2.19^{* * *} \\
(0.02)\end{array}$ & $\begin{array}{c}6.28^{* * *} \\
(0.03)\end{array}$ & & & & & \\
\hline $\begin{array}{l}\text { April } 23 \\
\text { 5:45 P.M. }\end{array}$ & $\begin{array}{c}-0.54^{* * *} \\
(0.02)\end{array}$ & $\begin{array}{c}-0.45^{* * *} \\
(0.03)\end{array}$ & $\begin{array}{c}-0.86^{* * *} \\
(0.02)\end{array}$ & $\begin{array}{c}-0.40^{* * *} \\
(0.03)\end{array}$ & & & & & \\
\hline $\begin{array}{l}\text { April } 27 \\
\text { 4:30 P.M. }\end{array}$ & $\begin{array}{c}0.48^{* * *} \\
(0.02)\end{array}$ & $\begin{array}{c}0.46^{* * *} \\
(0.03)\end{array}$ & $\begin{array}{c}-0.12^{* * *} \\
(0.02)\end{array}$ & $\begin{array}{c}2.12^{* * *} \\
(0.03)\end{array}$ & & & & & \\
\hline $\begin{array}{l}\text { April } 30 \\
\text { 10:00 A.M. }\end{array}$ & $\begin{array}{c}0.35^{* * *} \\
(0.02)\end{array}$ & $\begin{array}{c}0.43^{* * *} \\
(0.03)\end{array}$ & $\begin{array}{c}0.03 \\
(0.02)\end{array}$ & $\begin{array}{c}0.72^{* * *} \\
(0.03)\end{array}$ & & & & & \\
\hline Constant & $\begin{array}{l}-0.01 \\
(0.01)\end{array}$ & $\begin{array}{l}-0.01 \\
(0.01)\end{array}$ & $\begin{array}{l}-0.00 \\
(0.01)\end{array}$ & $\begin{array}{l}-0.02 * \\
(0.01)\end{array}$ & & & & & \\
\hline Obs. & 3,470 & 3,470 & 3,470 & 3,469 & Obs. & 3,470 & 3,470 & 3,470 & 3,469 \\
\hline Sum & $1.53^{* * *}$ & $0.92^{* * *}$ & $3.64^{* * *}$ & $6.98^{* * *}$ & Sum & $-17.07^{* * *}$ & $-16.61^{* * *}$ & $-16.90^{* * *}$ & $-21.43^{* * *}$ \\
\hline F-test & 47.1 & 15.3 & 271.0 & 797.1 & F-test & 33364.8 & 27985.9 & 33694.7 & 39520.2 \\
\hline
\end{tabular}

Fed Announcement Effects on S\&P 500 Stock Index Changes. The table reports the sum of the coefficients from a regression of 30-minute price changes on two dummy variables that take the value 1 in the 10-minute interval that contains the event and the 10 -minute interval after the event. Heteroskedasticity robust standard errors for the sum appear in parentheses. For events that occur in trading hours, the left-hand-side variable is the log difference between the price 20 minutes after and 10 minutes before the event. For events that occur outside of trading hours, the left-hand-side variable is the log difference between the price 20 minutes after the market opens on the first day after the announcement, and the most recent closing price. The sample spans the period of January 1st of 2020 to May 5th of 2020 . Robust Standard Errors: *sig. at $10 \%$. ${ }^{* *}$ sig. at $5 \%$. ${ }^{* * *}$ sig. at $1 \%$. 
Table 4: Event Study: Supportive Unconventional Announcements

\begin{tabular}{lcccc}
\hline \hline & \multicolumn{4}{c}{ Unconventional } \\
Event Date & S\&P500 & DJI & Nasdaq & Russ.2000 \\
\hline March 17 & $2.65^{* * *}$ & $2.09^{* * *}$ & $3.27^{* * *}$ & $0.67^{* * *}$ \\
10:45 A.M. & $(0.02)$ & $(0.03)$ & $(0.02)$ & $(0.03)$ \\
& & & & \\
March 20 & $1.80^{* * *}$ & $1.56^{* * *}$ & $1.63^{* * *}$ & $2.22^{* * *}$ \\
10:00 A.M. & $(0.02)$ & $(0.03)$ & $(0.02)$ & $(0.03)$ \\
& & & & \\
April 9 & $3.00^{* * *}$ & $2.94^{* * *}$ & $2.19^{* * *}$ & $6.29^{* * *}$ \\
8:30 A.M. & $(0.02)$ & $(0.03)$ & $(0.02)$ & $(0.03)$ \\
& & & & \\
April 27 & $0.49^{* * *}$ & $0.46^{* * *}$ & $-0.12^{* * *}$ & $2.12^{* * *}$ \\
4:30 P.M. & $(0.02)$ & $(0.03)$ & $(0.02)$ & $(0.03)$ \\
& & & & \\
April 30 & $0.36^{* * *}$ & $0.44^{* * *}$ & $0.03^{* * *}$ & $0.73^{* * *}$ \\
10:00 A.M. & $(0.02)$ & $(0.03)$ & $(0.02)$ & $(0.03)$ \\
& & & & \\
Constant & -0.01 & -0.01 & -0.00 & $-0.03^{*}$ \\
& $(0.01)$ & $(0.01)$ & $(0.01)$ & $(0.01)$ \\
\hline Obs. & 3,470 & 3,470 & 3,470 & 3,469 \\
Fum & $8.30^{* * *}$ & $7.48^{* * *}$ & $7.00^{* * *}$ & $12.03^{* * *}$ \\
\hline \hline
\end{tabular}

Fed Announcement Effects on S\&P 500 Stock Index Changes. The table reports the sum of the coefficients from a regression of 30 -minute price changes on two dummy variables that take the value 1 in the 10-minute interval that contains the event and the 10 -minute interval after the event. Heteroskedasticity robust standard errors for the sum appear in parentheses. For events that occur in trading hours, the left-hand-side variable is the log difference between the price 20 minutes after and 10 minutes before the event. For events that occur outside of trading hours, the left-hand-side variable is the log difference between the price 20 minutes after the market opens on the first day after the announcement, and the most recent closing price. The sample spans the period of January 1st of 2020 to May 5th of 2020 . Robust Standard Errors: *sig. at $10 \%$. **sig. at $5 \%$. ***sig. at $1 \%$. 


\section{A Appendix}

\section{A.1 Federal Reserve Announcements}

Table 5: FED Announcements

\begin{tabular}{|c|c|c|c|c|}
\hline Date & Day & Hour & Event & Information \\
\hline \multicolumn{5}{|r|}{ March } \\
\hline $3 / 3 / 20$ & Tuesday & 10:00 AM & FOMC Statement & 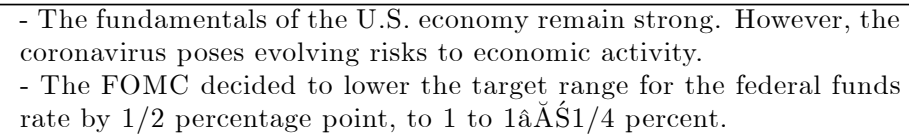 \\
\hline $3 / 15 / 20$ & Sunday & 5:00 PM & FOMC Statement & $\begin{array}{l}\text { - The coronavirus outbreak has harmed communities and disrupted } \\
\text { economic activity in many countries, including the United States. } \\
\text { Global financial conditions have also been significantly affected. } \\
\text { - The FOMC decided to lower the target range for the federal funds } \\
\text { rate by } 1 \text { percentage point, to } 0 \text { to } 1 / 4 \text { percent. } \\
\text { - The Committee expects to maintain this target range until it is } \\
\text { confident that the economy has weathered recent events and is on } \\
\text { track to achieve its maximum employment and price stability goals. } \\
\text { - Over coming months the Committee will increase its holdings of } \\
\text { Treasury securities by at least } \$ 500 \text { billion and its holdings of agency } \\
\text { MBS by at least } \$ 200 \text { billion. }\end{array}$ \\
\hline $3 / 17 / 20$ & Tuesday & $10: 45 \mathrm{AM}$ & Creation CPFF & $\begin{array}{l}\text { - The Federal Reserve Board announced today that it will establish } \\
\text { a Commercial Paper Funding Facility (CPFF) to support the flow of } \\
\text { credit to households and businesses. } \\
\text { - The CPFF will provide a liquidity backstop to U.S. issuers of com- } \\
\text { mercial paper through a special purpose vehicle (SPV) that will pur- } \\
\text { chase unsecured and asset-backed commercial paper rated A1/P1 (as } \\
\text { of March } 17,2020 \text { ) directly from eligible companies. }\end{array}$ \\
\hline $3 / 17 / 20$ & Tuesday & 6:00 PM & Creation PDCF & $\begin{array}{l}\text { - The Federal Reserve Board on Tuesday announced that it will es- } \\
\text { tablish a Primary Dealer Credit Facility (PDCF). } \\
\text { - The PDCF will offer overnight and term funding with maturities up } \\
\text { to } 90 \text { days and will be available on March } 20,2020 \text {. It will be in place } \\
\text { for at least six months and may be extended as conditions warrant. }\end{array}$ \\
\hline $3 / 18 / 20$ & Wednesday & 11:30 PM & Creation MMLF & $\begin{array}{l}\text { - The Federal Reserve Board establishes a Money Market Mutual } \\
\text { Fund Liquidity Facility (MMLF) which will make loans available to } \\
\text { eligible financial institutions secured by high-quality assets purchased } \\
\text { by the financial institution from money market mutual funds. } \\
\text { - The MMLF will assist money market funds in meeting demands for } \\
\text { redemptions by households and other investors. } \\
\text { - The MMLF program will purchase a broader range of assets, but } \\
\text { its structure is very similar to the Asset-Backed Commercial Paper } \\
\text { Money Market Mutual Fund Liquidity Facility, or AMLF, that oper- } \\
\text { ated from late } 2008 \text { to early } 2010 \text {. }\end{array}$ \\
\hline $3 / 19 / 20$ & Thrursday & 9:00 AM & $\begin{array}{lr}\text { Dollar } & \text { liquidity } \\
\text { arrangements } & \text { with } \\
\text { other CBs } & \end{array}$ & $\begin{array}{l}\text { - The Federal Reserve announces the establishment of temporary U.S. } \\
\text { dollar liquidity arrangements with other central banks. } \\
\text { - These new facilities will support the provision of U.S. dollar liquidity } \\
\text { in amounts up to } \$ 60 \text { billion each for the Reserve Bank of Australia, } \\
\text { the Banco Central do Brasil, the Bank of Korea, the Banco de Mexico, } \\
\text { the Monetary Authority of Singapore, and the Sveriges Riksbank and } \\
\$ 30 \text { billion each for the Danmarks Nationalbank, the Norges Bank, } \\
\text { and the Reserve Bank of New Zealand. } \\
\text { - These U.S. dollar liquidity arrangements will be in place for at least } \\
\text { six months. }\end{array}$ \\
\hline
\end{tabular}




\begin{tabular}{|c|c|c|c|}
\hline $3 / 20 / 20$ & Friday & 10:00 AM & $\begin{array}{lr}\text { Expand } & \text { liquidity } \\
\text { arrangements } & \text { with } \\
\text { other CBs } & \end{array}$ \\
\hline $3 / 23 / 20$ & Monday & 8:00 AM & FOMC Statement \\
\hline $3 / 23 / 20$ & Monday & 8:00 AM & $\begin{array}{l}\text { - Creation of PMCCF } \\
\text { - Creation of SMCCF } \\
\text { - Creation of TALF } \\
\text { - Expand the MMLF } \\
\text { - Expand CPFF }\end{array}$ \\
\hline
\end{tabular}

- The Bank of Canada, the Bank of England, the Bank of Japan, the European Central Bank, the Federal Reserve, and the Swiss National Bank are today announcing a coordinated action to further enhance the provision of liquidity via the standing U.S. dollar liquidity swap line arrangements.

- These central banks have agreed to increase the frequency of 7-day maturity operations from weekly to daily. These daily operations will commence on Monday, March 23, 2020, and will continue at least through the end of April. The central banks also will continue to hold weekly 84-day maturity operations.

- The Federal Reserve will continue to purchase Treasury securities and agency MBS in the amounts needed to support smooth market functioning and effective transmission of monetary policy to broader financial conditions.

- Supporting the flow of credit to employers, consumers, and businesses by establishing new programs that, taken together, will provide up to $\$ 300$ billion in new financing. The Department of the Treasury, using the Exchange Stabilization Fund (ESF), will provide $\$ 30$ billion in equity to these facilities.

- Establishment of two facilities to support credit to large employers âĂŞ the Primary Market Corporate Credit Facility (PMCCF) for new bond and loan issuance and the Secondary Market Corporate Credit Facility (SMCCF) to provide liquidity for outstanding corporate bonds.

- Establishment of a third facility, the Term Asset-Backed Securities Loan Facility (TALF), to support the flow of credit to consumers and businesses. The TALF will enable the issuance of asset-backed securities (ABS) guaranteed by the Small Business Administration (SBA). - Facilitating the flow of credit to municipalities by expanding the Money Market Mutual Fund Liquidity Facility (MMLF) to include a wider range of securities, including municipal variable rate demand notes (VRDNs) and bank certificates of deposit.

- Facilitating the flow of credit to municipalities by expanding the Commercial Paper Funding Facility (CPFF) to include high-quality, tax-exempt commercial paper as eligible securities.

- The FED expects to announce soon the establishment of a Main Street Lending Program (MSLP) to support lending to eligible smalland-medium sized businesses, complementing efforts by the SBA.

3/31/20 Tuesday 8:30 AM Creation of FIMA Repo Facility repurchase agreement facility for foreign and international monetary authorities (FIMA Repo Facility)

- FIMA account holders temporarily exchange their U.S. Treasury securities held with the Federal Reserve for U.S. dollars, which can then be made available to institutions in their jurisdictions.

- The FIMA Repo Facility will be available beginning April 6 and will continue for at least 6 months.

\begin{tabular}{|c|c|c|c|c|}
\hline \multicolumn{5}{|r|}{ April } \\
\hline $4 / 6 / 20$ & Monday & 2:00 PM & $\begin{array}{l}\text { Creation of a facility to } \\
\text { provide term financing } \\
\text { backed by PPP loans }\end{array}$ & $\begin{array}{l}\text { - Federal Reserve will establish a facility to facilitate lending to small } \\
\text { businesses via the Small Business Administration (SBA)'s Paycheck } \\
\text { Protection Program (PPP) by providing term financing backed by } \\
\text { PPP loans }\end{array}$ \\
\hline $4 / 8 / 20$ & Wednesday & 2:00 PM & Minutes Release & \\
\hline
\end{tabular}


-Provide up to $\$ 2.3$ trillion in loans.

- Bolster SBA's PP. PLF.

- Creation of the MSLP.

- Expand the PMCCF, SMCCF, and TALF.
$4 / 9 / 20 \quad$ Thursday

$4 / 23 / 20 \quad$ Thursday

4/27/20 Monday

4:30 PM

4/29/20 Wednesday 2:00 PM FOMC Statement

4/30/20 Thursday

10:00 AM

Expansion of the scope and eligibility for the MSLP.
Chairman Speech

Announcement of future expansion of the PPPLF

Expansion of the scope and duration of the MLF.
The FED takes additional actions to provide up to $\$ 2.3$ trillion in loans to support the economy. The actions the Federal Reserve is taking today to support employers of all sizes and communities across the country will:

- Bolster the effectiveness of the Small Business Administration's PPPLF. The PPPLF provides loans to small businesses so that they can keep their workers on the payroll.

- Ensure credit flows to small and mid-sized businesses with the purchase of up to $\$ 600$ billion in loans through the Main Street Lending Program (MSLP). Eligible companies are the ones employing up to 10,000 workers or with revenues of less than $\$ 2.5$ billion.

- Expand the size and scope of the PMCCF and SMCCF as well as the TALF. These three programs will now support up to $\$ 850$ billion in credit backed by $\$ 85$ billion in credit protection provided by the Treasury. TALF-eligible collateral will now include the triple-A rated tranches of both outstanding commercial mortgage-backed securities and newly issued collateralized loan obligations.

- Establish a Municipal Liquidity Facility (MLF) that will offer up to $\$ 500$ billion in lending to states and municipalities.

- COVID-19 and the Economy

- The Federal Reserve announces it is working to expand access to its Paycheck Protection Program Liquidity Facility (PPPLF) for additional SBA-qualified lenders as soon as possible.

- The Federal Reserve Board on Monday announced an expansion of the scope and duration of the Municipal Liquidity Facility (MLF). The facility, which was announced on April 9 as part of an initiative to provide up to $\$ 2.3$ trillion in loans to support U.S. households, businesses, and communities, will offer up to $\$ 500$ billion in lending to states and municipalities to help manage cash flow stresses caused by the coronavirus pandemic.

- The Federal Reserve will continue to purchase Treasury securities and agency residential and commercial mortgage-backed securities in the amounts needed to support smooth market functioning, thereby fostering effective transmission of monetary policy to broader financial conditions.

- In addition, the Open Market Desk will continue to offer large-scale overnight and term repurchase agreement operations.

- The Committee will closely monitor market conditions and is prepared to adjust its plans as appropriate.

The changes include:

- Creating a third loan option, with increased risk sharing by lenders for borrowers with greater leverage.

- Lowering the minimum loan size for certain loans to $\$ 500,000$.

- Expanding the pool of businesses eligible to borrow: businesses with up to 15,000 employees or up to $\$ 5$ billion in annual revenue are now eligible, compared to the initial program terms, which were for companies with up to 10,000 employees and $\$ 2.5$ billion in revenue.

$\begin{array}{ll}\text { 4/30/20 Thursday 5:15 PM } & \begin{array}{l}\text { Expansion of the PP- } \\ \text { PLF. }\end{array}\end{array}$

- Federal Reserve expands access to its Paycheck Protection Program Liquidity Facility (PPPLF) to additional lenders, and expands the collateral that can be pledged.

\section{May}

5/11/20 Monday 10:30 AM Updates for the MLF.

ipal

- The MLF will offer up to $\$ 500$ billion in lending to states and municipalities to help manage cash flow stresses caused by the coronavirus pandemic.

5/12/20 Tuesday 1:15 PM Updates for the TALF.
- Federal Reserve publishes updates to the term sheet for the Term Asset-Backed Securities Loan Facility (TALF) and announces information to be disclosed monthly for the TALF and the Paycheck Protection Program Liquidity Facility.

- The facility was announced on March 23 as part of an initiative to support the flow of credit to U.S. consumers and businesses. To help ensure that U.S. consumers and businesses remain able to access credit at affordable terms, TALF initially will make up to $\$ 100$ billion of loans available. 


\section{A.2 Data}

CORP. NET VALUE ADDED, CORP. LABOR COMPENSATION, CORP. AFTER-TAX PROFITS, TAXES AND INTEREST

Data for the net value added $(N V A)$ comes from NIPA Table 1.14 (corporate sector series codes A457RC1 and A438RC1). We use the implicit price deflator for net value added. After tax profits (ATP) for the domestic sector come from NIPA Table 1.14 (corporate sector series code: W273RC1). Corporate sector labor compensation (LC) for the domestic sector is from Table 1.14 (series code A442RC).

\section{PRICE DEFLATOR}

A chain-type price deflator for the nonfinancial corporate sector (NFCS) is obtained implicitly by dividing the net value added of nonfinancial corporate business by the chained real dollar net value added of nonfinancial corporate business from NIPA Table 1.14. This index is used to deflate net value added of the corporate sector. There is no implicit price deflator available for the whole corporate sector, so we use deflator for the non-financial corporate sector instead.

\section{STOCK PRICE INDEXES}

Data for stock price indexes is obtained from FirstRateData Historical Dataset. FirstRate Data provides intraday stock market indexes. They source data direct from major exchanges and test all datasets for consistency and completeness. We use the US Indices - Historical Intraday Price Data which includes 1-minute historical intraday data for 15 major US indices (https://firstratedata.com/).

\section{FEDERAL RESERVE BALANCE SHEET AND OUTSTANDING CREDIT}

Data for the FED balance sheet is obatained from the Federal Reserve Bank of Cleveland. The bank of Cleveland groups the assets on the Fed balance sheet to show the evolution of different types of assets (https://www.clevelandfed.org/en/our-research/indicators-anddata/credit-easing.aspx). Outstanding credit from new and expanded facilities is obtained from the Reports to Congress Pursuant to Section 13(3) of the Federal Reserve Act in response to COVID-19 (https://www.federalreserve.gov/publications/reports-to-congress-inresponse-to-covid-19.htm). 